\title{
Relationship between School Climate and Early Years Teachers Professional Identity in Kenya
}

DOI: https://doi.org/10.47175/rielsj.v2i3.319

\author{
| Phyllis M. Magoma ${ }^{1}$ | \\ 1,2,3 Department of Early \\ Childhood \& Special Needs \\ Education Kenyatta University
}

${ }^{1}$ phyllismagoma2@gmail.com

${ }^{2}$ mwoma.teresa@gmail.com

${ }^{3}$ waithaka.esther@gmail.com

\section{Teresa Mwoma² | Esther Waithaka ${ }^{3}$ |}

\begin{abstract}
This mixed methods research examined the relationship between school climate and early year's teachers' professional identity. Using a sample of 220 teachers in 44 schools, the researcher established that early years teachers' professional identity was weak and school climate had an effect on the teachers' professional identity. This article's findings confirmed that among school climate variables safety in school, high teacher-pupil ratio, lack of adequate physical facilities, teachers not involved in decision making, poor working environment, heavy work load and lack of enough teaching-learning materials, as having a negative impact on the teachers professional identity. Lastly, in order to boost EYET (Early Years Education Teachers) professional identity, provision of positive climates in schools was found to be imperative.

KEYWORDS

Correlation; school climate; early years' education; teachers' professional identity; Kenya.
\end{abstract}

\section{INTRODUCTION}

Positive school climates foster teacher's sense of self efficacy resulting into job satisfaction and retention (Katsantonis, 2019). Similarly, school climates can propel teachers to execute their work to the fullest potential or weaken their determination to do so (Kraft \& Falken, 2020). It is one of the dominant factors in determining educational achievement (Chirkina $\&$ Khaveson, 2018). Provision of a positive school climate for teachers also creates a sturdy learning environment for pupils. Universally, there is lack of a common definition of the concept school climate. This is because the construct is complex and multifaceted covering a wide range of aspects such as safety, interpersonal relationships, institutional environment and finally, the teaching and learning processes. Nonetheless, here is how a few scholars have defined it; According to Osher, Neiman and Williamson (2018) school climate is the term used to describe how people experience the school environment. That is, their interactions and experiences within given educational settings. They further expound that it encompasses the collective and emotive conditions for learning, teaching, safety experiences, support and academic focus not forgetting individual and cultural respect.

Thapa, Cohen, Guffey, and Higgins-D'Alessandro (2013) opine that school climate describes the school's physical features such as buildings, students and staff demographics, rules and social interactions between individuals and lastly, beliefs and values of individuals within the school. Rennie Research Centre, (2017) also describe school climate to the character and quality of a school's culture and environment.

Extensive research done has revealed that school climate is a leading factor affecting how students learn and achieve academically (Collins \& Parson, 2010; Kraft \& Falken, 2020; Chein \& Weikart, 2008, Thapa etal 2013). Likewise, it has been linked to the students' emotional and behavioural outcomes (Brand, Felner, Seitsinger \& Burns, 2008). However, 
whether school climate influences professional identity of EYE teachers is an issue which is not clear and needs to be explored. Central to this research is the overarching question of whether EYE teachers' professional identity could be influenced by climate in schools. This article presents findings to that effect.

Teachers' impacts on learners' outcomes are well-evidenced in research. Teachers have the largest effect when it comes to learning of children more than all other school reforms (Schater \& Thum, 2004). Teachers, who work in positive school climates, get better quickly, stay longer and are able to thrust learners to greater elevations. The day to day working experiences of teachers is directly influenced by the environment in schools that is why it was imperative for the researcher to conduct this study so as to explore if EYE teachers professional identity has a relationship with school climate.

Studies done (Mosomi,2015; Collie, Shapka, and Perry 2012) have associated school climate with EYE teachers job dissatisfaction and low motivation levels but there is a dearth of literature examining school climate and its relationship to EYE teachers professional identity. Seeking to fill this gap the current article explores whether there do exist a relationship between school climate and teachers professional identity.

Professional identity is a construct which is used to describe what one does and how to communicate to others who they are in their profession (Beijaard, Verloop \&Vermunt 2004). It is based on a set of beliefs, attitudes and understanding about ones professional role. Research has illustrated that teachers' professional identity is a key determinant of how effective they will work, their motivation level, commitment, psychological well-being and insistence in the profession (Jermolajeva, Bogdanova, \& Silchenkova 2018). Similarly, Ahmad, Wahab, Shah and Khan (2018) posit that teacher's professional identity is directly linked to student learning outcomes. They further argue that when teachers' professional identity is improved, there is a positive direct effect on the learners' achievement academically. It has also been linked to teacher quality, a factor which influences how pupils learn.

Intercontinentally, early childhood teachers' professional identity is an issue which has attracted a lot of attention. In USA, England, Greece, Barbados and Australia there is lack of clarity when it comes to the professional identity of early years teachers. The teacher's professional identity is bounded by unsteadiness as a result of low pay, low public perception and lack of common credentials. The situation exhibited above isn't any different both regionally and locally.

Studies did have linked weak early year's teachers' professional identity to factors such as low job satisfaction and motivation levels. There is limited literature concerning early year's teachers' professional identity and its relationship to school climate. The current study sought to fill this gap. Conclusively, for effective teaching and learning in our early years education centres, the concepts of teachers professional identity and school climate had to be explored in-depth.

\section{Objectives of the Study}

(i) To establish early years teachers' professional identity.

(ii) To find out the relationship between school climate and early year teachers' professional identity.

\section{Theoretical Framework}

Fredrick Herzberg's (1950) theory of satisfaction and motivation was employed to guide the study. The theory postulates that satisfaction of employees in their places of work is affected by two sets of issues: 'hygiene' and 'motivators'. 
Issues of hygiene deal with the employees' working environments such as; school managerial policies, salary payments, working conditions and interpersonal relations. These issues help to reduce dissatisfaction among employees when addressed well. The school management should also ensure working environment (school climate) is conducive by providing enough furniture, adequate office space, tools and equipment for teaching-learning so as to make the teachers work easier. Motivator issues fulfil teachers' individual needs. They are concerned with aspects such as accomplishment, appreciation and professional growth. Herzberg also adds that teachers should be involved in decision making, treated and respected as professionals.

\section{RESEARCH METHODS}

This article adopted a mixed research methodology which combines both qualitative and quantitative methods in data collection. When doing research, Creswell and Clark (2007) assert that integrating the two methodologies yields better understanding of the research topic than when one is used. Concurrent research design was employed in this study because it enabled the researcher to gather wide-ranging data from a large group of respondents in just one phase. Similarly, EYE teachers' professional identity and its relationship with school climate were tackled both quantitatively and qualitatively.

\section{Location of the Study}

The study was conducted in Kasarani Sub-county in Nairobi City County. There are 145 public and private primary schools in Kasarani Sub-county in Nairobi City County in Kenya with pre-primary schools attached, whose EYE teachers were targeted for participation in the study.

\section{Sampling Techniques and Sample Size}

This study used purposive sampling method to come up with the study location that is Kasarani Sub-county in Nairobi City County. Stratified random sampling method was then used to select $30 \%(145)$ of the pre-primary and lower primary schools in the area to participate in the study. Random sampling technique was employed to select 5 teachers from each school. All head teachers from the sampled schools were selected. The sample consisted of 44 schools, 44 head teachers and 220 teachers.

\section{Research Instruments}

Questionnaires and interview schedules were used for data collection. The research instruments aided the researcher in gathering rich and comprehensive data concerning EYE teachers' professional identity and school climate. Questionnaires made it possible for the researcher to measure EYE teachers' professional identity and school climate whereas interviews were used to examine EYE teachers' professional identity and its relationship to school climate in depth. Another reason why the researcher decided to use multiple data tools was to allow for triangulation of data.

\section{Pilot Study}

Before actual data collection, instruments were piloted in two schools randomly sampled from the sub-county; one public and the other private which were not to be part of the main study. Pilot results of aided the researcher to evaluate queries in the questionnaires and those in the interview schedules. This therefore ensured that questions were clear to the participants. To ensure that the research tools measured what they were intended to measure, content validity was used. Reliability of the interviews was established through test-retest 
method. This was done by administering the instruments twice to the same respondents at different times and the results were compared and because the results were similar the instruments were considered reliable.

\section{Data Collection anda Analysis}

Quantitative data was garnered using questionnaires whereas qualitative data was collected by use of semi-structured interview schedules. Data were collected in three stages as follows: firstly, questionnaires were administered to teachers in their respective schools; subsequently selected teachers were interviewed after administration of the questionnaires and finally, head teachers were also interviewed. Statistical methods were used to evaluate quantitative data while qualitative data was scrutinized using content and theme analysis. Each data was analysed separately and triangulation of the results done during interpretation phase.

\section{Logistical and Ethical Considerations}

Permission was obtained from various organizations before the researcher commenced on data collection. To protect the participants' confidentiality, they were identified using codes instead of real names. Participants were also guaranteed of concealment and anonymity of the data they were to give.

\section{RESULTS AND DISCUSSIONS}

\section{Early Years Teachers' Professional Identity}

Objective one of this article sought to establish EYE teachers' professional identity. To accomplish this, the researcher used questionnaires and conducted interviews on the teachers. Table 1 presents the findings.

Table 1. Mean Scores in Teachers' Professional Identity

\begin{tabular}{|c|c|c|c|c|c|}
\hline \multicolumn{6}{|l|}{ Professional identity } \\
\hline & $\mathbf{N}$ & Min & Max & Mean & Std. \\
\hline Happy to be EYE teacher & 220 & 1 & 5 & 2.65 & 1.13 \\
\hline Pursuing a career in early years education is important to me & 220 & 1 & 5 & 3.32 & 1.21 \\
\hline My job has a professional status & 220 & 1 & 5 & 1.18 & .55 \\
\hline My job is respected by our society & 220 & 1 & 5 & 1.15 & .42 \\
\hline There is a career progression in my school & 220 & 1 & 5 & 1.96 & 1.11 \\
\hline The work I do in this school helps me to grow in my profession & 220 & 1 & 5 & 1.80 & 1.14 \\
\hline I have adequate knowledge, skills and understanding of ECE & 220 & 1 & 5 & 4.19 & .93 \\
\hline $\begin{array}{l}\text { I select and use appropriate teaching and learning methods and } \\
\text { strategies to enhance children's learning }\end{array}$ & 220 & 1 & 5 & 4.28 & .87 \\
\hline $\begin{array}{l}\text { I am able to create conducive learning environment for children } \\
\text { in my class }\end{array}$ & 220 & 1 & 5 & 4.37 & .83 \\
\hline I am able to motivate children in my class to learn & 220 & 1 & 5 & 4.34 & .80 \\
\hline $\begin{array}{l}\text { I am able to assess children's learning and use the results to } \\
\text { improve their learning }\end{array}$ & 220 & 1 & 5 & 4.31 & .90 \\
\hline I am able to support diverse learning needs of children & 220 & 1 & 5 & 4.17 & .91 \\
\hline I can identify positively with members of the teaching profession & 220 & 1 & 5 & 4.11 & .88 \\
\hline $\begin{array}{l}\text { Being a member of the teaching profession is very important to } \\
\text { me }\end{array}$ & 220 & 1 & 5 & 4.24 & .94 \\
\hline I share new teaching ideas with my colleagues & 220 & 1 & 5 & 4.27 & .82 \\
\hline $\begin{array}{l}\text { I participate in early years educators in-service training courses } \\
\text { and seminars to develop my career }\end{array}$ & 220 & 1 & 5 & 1.70 & .74 \\
\hline I am a member of the ECE profession network & 220 & 1 & 5 & 2.15 & .92 \\
\hline
\end{tabular}


As displayed in Table 1 the means for professional identity indicators ranged from $1.15(\mathrm{SD}=.42)$ to $4.37(\mathrm{SD} .83)$. Further scrutiny of the results revealed that individual mean scores for the following indicators of professional identity; teachers' professional status, respect of the job by the society, career progression in the school, work helping teachers to grow in the profession, participating in early years in-service training courses, being a member of professional network were very low.

From the interviews conducted, EYE teachers' professional identity was found to be weak. According to the interview results it emerged that the professional identity was weak because teachers reported being perceived as caregivers rather than teachers, seen as doing little work, taken as low academic achievers, earned low salaries and negative treatment from the society.

The following are some of their sentiments.

The society perceives our work as inferior. They take us as caregivers rather than teachers. They take our work for granted. They think our work is to wipe children mucus, take them to the toilet and hence they do not respect us. They say it is a tiresome work with low income. They don't take our work seriously; to them we are like failures (Preprimary Teacher in Private School 1).

Our work as pre-primary school teachers is perceived with little weight. Most people believe we get low salaries of which it is true. They take us as low academic achievers. Some people see us as house helps or rather people who just missed something else to do in life. It's considered as the lowest paying profession because we are believed to be failures (Pre-primary Teacher in Public School 3).

Interviews conducted in this study indicated that early years teachers' professional identity was weak because the society was not viewing them as teachers, their job was not respected by society and it had a low professional status. There was no career progression in schools, teachers said that they were considered as low class persons and taken as academic failures. These findings concur with those from Boyd (2013) who in an in-depth interview with early childhood educators found that the teachers' professional identity was weak. Many of the educators had expressed their frustration on the society's perception as child caregivers rather than teachers. Recognition for them was also a problem since they said it was little or none at all. Although they saw their work as important the society didn't give them any respect for the work they do and as a result they intended to leave the early year's education field results which are in compliance to the findings of this study.

Moloney (2015) found that many early years teachers were struggling for professional status and recognition. She further explains that terming the work of the teachers as care giving is devaluing it and this in return impacts people's sense of how much the early years teachers are to be paid or their job worth. This finding concurs with the current study results that which had revealed EYE teachers were not given recognition nor respected by the society for the work they do and were seen as caregivers rather than teachers.

Barford and Whelton (2010) as cited in Boyd (2013) had found that most early year's teachers find it difficult to get respect from the society and other professionals. They further elaborate that lack of respect from the society and other professionals hinders hiring and retaining of experienced qualified staff in the early years education sector. This finding correspond to the current study findings that many of the teachers interviewed intended to leave the profession due to little respect they are given by the society, low professional status and poor remuneration. 
Many of the teachers interviewed felt undervalued and underappreciated by both the national and county government and were left with no option but to search for better paying jobs elsewhere. These findings agree with Moloney and Pope (2013) study in Ireland, which explored the professional identity of early childhood education professionals in the sector. Results depicted a picture of frustration and disappointment among the professionals concerning their professional identity and status in society. It was also found that teaching in ECE was undervalued and underappreciated profession. Similarly, Madden (2012) claimed that in Ireland ECE is not recognized and valued as a profession and EYE teachers remained undervalued and underappreciated.

Lightfoot and Frost (2015) studied England's early years educators professional identity. Findings showed that early years educators displayed mixed feelings as well as disappointment with their role. Equally, in Ireland, Moloney (2010) did a study to explore professional identity of early childhood educators and found that their identity was argumentative and difficult results which are equivalent to the findings of this study which divulged that the early years teachers were seen as academic failures, their work was considered inferior and treated like they knew little like the pupils they were handling.

\section{School Climate and EYE Teachers Professional Identity}

Objective two examined if there was an association between the climate in schools and EYE teachers' professional identity. For this objective to be realized, climate in schools was measured first. This was done using a school climate survey questionnaire. Results are exemplified in Table 2.

Table 2. Mean Scores in School Climate

\begin{tabular}{llllll}
\hline School climate & N & Min & Max & Mean & Std. Dev \\
\hline School schedule allows planning & 220 & 1 & 5 & 4.35 & .75 \\
School environment is clean & 220 & 1 & 5 & 2.43 & 1.09 \\
I feel safe in my school & 220 & 1 & 5 & 2.76 & 1.16 \\
Managing children has challenges & 220 & 1 & 5 & 4.19 & .93 \\
My class enrollments are too large & 220 & 1 & 5 & 3.31 & 1.25 \\
Access to the tools needed to do good job & 220 & 1 & 5 & 3.86 & 1.05 \\
Satisfied with opportunities for professional growth & 220 & 1 & 5 & 4.16 & .76 \\
Look forward to Come to work in my school everyday & 220 & 1 & 5 & 4.40 & .54 \\
School retains best teachers & 220 & 1 & 5 & 4.33 & .73 \\
There is close working relationships & 220 & 1 & 5 & 4.29 & .81 \\
Teachers are treated with respect & 220 & 1 & 5 & 1.90 & .83 \\
I am proud to tell others that I work in this school & 220 & 1 & 5 & 3.34 & .69 \\
Teachers are recognized for work well done & 220 & 1 & 5 & 3.96 & .94 \\
Teachers are involved in decision making & 220 & 1 & 5 & 2.66 & 1.29 \\
I enjoy working in my school & 220 & 1 & 5. & 3.09 & 1.38 \\
\hline
\end{tabular}

As seen in Table 2, school climate facets mean scores ranged from 1.90 ( $\mathrm{SD}=.83)$ to 4.40 ( $\mathrm{SD}=.54)$. School climate items such as teachers getting involved in decision making, being treated with respect, safety in school and clean school environment scored lowly in the questionnaire.

Data from the interviews was also analysed so as to obtain more information on school climate and teachers professional identity. Whereas information from the questionnaires had shown that climate in schools was positive, results from interviews with the EYE teachers revealed that climate in most of the schools were negative. From interviews, some of the common factors contributing to negative climate in schools were: High teacher-pupil ratio; lack of adequate physical facilities; teachers not involved in decision making; poor working 
environment; heavy work load and lack of enough teaching-learning materials. Others were lack of proper terms and conditions of service, low salaries and non-existence of a workers union.

Teachers expressed the climate in their schools in various ways. The following are some of their sentiments:

There aren't enough teaching and learning resources required by the competencebased curriculum. This makes teaching and learning a difficult task. Many times we need materials to cater for learners individual differences which we lack. The textbooks we require in CBC re are not sufficient text (Lower Primary Teacher in Public School 4).

The teaching and learning facilities we have are not enough and the classes are too small for the number of pupils we have. We also don't have a playground to nurture the learner's talents as required by the competence-based curriculum (Pre-primary Teacher in Private School 27).

The working environment in our school is poor. That is we have overpopulated classes; the ratio of pupils to teachers is very high. With a large number of pupils being under one teacher, efficiency is compromised. The classes are not spacious enough rendering them in conducive for learning but we have to put up with them. The furniture are also not enough. Our school is also located in a noisy place (Lower primary teacher in Public School 7).

EYE teachers' interviews helped to obtain more information on how school climate influenced their professional identity. The teachers raised important concerns related to their working environments which according to Herzerberg's theory are 'hygiene' issues that cause employees dissatisfaction. The complaints included poor working environment, large numbers of pupils, inadequate furniture and physical facilities and many others. Negative school climate leads to weak teacher professional identity, teacher attrition, low productivity, poor quality services and ineffective implementation of curriculum.

Pearson product correlation coefficient was to evaluate whether there was a relationship which was significant between school climate and EYE teachers' professional identity. Results are depicted in Table 4.3.

Table 3. Pearson Correlation Coefficient between Teachers' Professional Identity and School Climate

\begin{tabular}{|c|c|c|c|}
\hline & & $\begin{array}{c}\text { Av professional } \\
\text { identity }\end{array}$ & $\begin{array}{c}\text { Av school } \\
\text { climate }\end{array}$ \\
\hline \multirow{3}{*}{$\begin{array}{ll}\text { Av } & \text { professional } \\
\text { identity } & \end{array}$} & Pearson Correlation & 1 & $.305^{* *}$ \\
\hline & Sig. (2-tailed) & & .000 \\
\hline & $\mathrm{N}$ & 220 & 220 \\
\hline \multirow{3}{*}{ Av school climate } & Pearson Correlation & $.305^{* *}$ & 1 \\
\hline & Sig. (2-tailed) & .000 & \\
\hline & $\mathrm{N}$ & 220 & 220 \\
\hline
\end{tabular}

Results in Table 3 indicate that the relationship between EYE teachers' professional identity and school climate was positive and significant $(r=.305, n=220 \mathrm{p}<0.01)$. These results also denote that the climate in schools influenced teachers' professional identity.

From the interviews it emerged that early years' teachers' experienced poor working environment in terms of lack of adequate physical facilities, heavy work load and deficiency of adequate teaching-learning resources. These results agree with those of Karousiu, 
Hajisoteriou and Angelides (2019) who investigated the manner in which teachers' professional identity was affected within diverse settings in Cyprus. Findings revealed that teachers' professional identity kept changing with educational settings besides contextual factors like work increment, resources shortage and lack of respect, influenced the identity of teachers.

An evaluation of 59 qualitative studies carried out by Lankveld, Schoonenboom, Volman, and Beishuzen (2016) investigating factors which strengthen or weaken the formation of teachers' professional identity in higher learning institutions, revealed that staff development programmes and direct work environment had an impact on teachers' professional identity. These results concur with the current research findings which had found that the working environment inform of lack of proper terms and conditions of service, not being members of a union and low salaries as some of the factors which were impacting on early years teachers professional identity.

Isotaro (2017) conducted a study which examined the relationship between teacher educator professional identities, factors affecting the identity formation and their working environment in Eritrea. Results showed that inadequate working resources, poor infrastructure, heavy teaching loads and inadequate compensation affected the educators' professional identities. These findings are similar with the current research results which demonstrated that inadequate physical facilities, poor working relationships, overcrowded classrooms and heavy work load as the factors which affected pre-primary EYE teachers' professional identity.

Results of the present research established that the association between EYE teachers' professional identity and school climate was highly significant. These findings are supported by those of a study conducted by Raman, Ling and Khalid (2015) in Malaysia who explored the relationship between teachers commitment to work and school climate. Results showed that the climate in schools was related to teachers' commitment. Additionally, the current study findings revealed that the climate in schools affected the early year's teacher's professional identity results which are in line with Dronnesmund (2015) study in Sweden which had found that based on teachers' perspectives, preschool teachers professional identity was affected by working conditions in their schools.

\section{CONCLUSION}

The first objective was aimed at establishing EYE teachers' professional identity. Findings revealed that EYE teachers' professional identity was weak. This was because of factors such as poor remuneration, negative treatment by the society, not considered as professionals and regarded as less qualified, not being involved in decision making by school management, not employed by national government, county governments employed them as caregivers instead of teachers and they lacked proper terms and conditions of service when employed. Other reasons were; being considered to be low academic achievers, low ranking of their profession and lack of role appreciation by the school management. Most teachers displayed a range of feelings which created a picture of frustration and disappointment regarding their professional identity. The second objective examined whether there was a relationship between school climate and teachers professional identity. Results disclosed that there was a significant relationship between the climate in schools and teachers professional identity $(r=.305, \mathrm{p}=.000)$. This correlation implies that teachers who had a strong professional identity were likely to be from schools with a positive climate. The climate in schools was diverse ranging from negative to positive depending on the working environment, type and location of the school. 


\section{REFERENCES}

Ahmad, H., Wahab, N., Shah, S. \& Khan, S. (2018). Shaping professional identity through professional development: A retrospective study of TESOL professionals. International Journal of English Linguistics. Vol 8, (6) 37.

Barford, S., \& Whelton, W. (2010). Understanding burn out in child and youth care workers. Child and Youth Care Forum, 39(4)271-287.

Beijaard, D., Meijjer, P., \&Verloop, N. (2004). Reconsidering research on teachers professional identity. Teaching and Teacher Education.20 (2), 107-128.

Boyd, M. (2013). "I love my work but.......'the professionalization of early childhood education. The Qualitative Report, Vol 18,(36), 1-20.

Brand, S., Felner, R. D., Seitsinger, A., Burns, A., and Bolton, N. (2008). A large scale study of the assessment of the social environment of middle and secondary schools: the validity and utility of teachers' ratings of school climate, cultural pluralism, and safety problems for understanding school effects and school improvement. J. Sch. Psychol. 46, 507-535. doi: $10.1016 /$ j.jsp.2007.12.001

Chen, G., \& Weikart, L. A. (2008). Student background, school climate, school disorder, and student achievement: An empirical study of New York City's middle schools. J. Sch. Violence 7, 3-20. doi: 10.1080/15388220801973813

Chirkina,T \& Khaveson,T.(2018). School climate: A history of the concept and approaches to the defining and measuring it on PISA questionnaire. Russian Education Society. 60(2), 133-160.

Collie, R. J., Shapka, J. D., and Perry, N. E. (2012). School climate and social emotional learning: Predicting teacher stress, job satisfaction, and teaching efficacy. J. Educ. Psychol. 104, 1189-1204. doi: 10.1037/a0029356

Collins, T. N., and Parson, K. A. (2010). School climate and student outcomes. J. Cross Discipl. Perspect. Educ. 3, 34-39.

Creswell, J., \& Plano Clark, V. (2007). Designing and Conducting Mixed Methods Research. Thousand Oaks, CA: Sage Publications.

Dronnesmund, T. (2015). Preschool teachers 'professionalism: A question of education and competence. (Master's thesis: University of Gothenburg).

Isotaro, S. (2017). Teacher educators' professional identity formation in challenging context: Experience from Eritrea. (Master's thesis).University of Jyvaskyla: Eritrea.

Jermolajeva, J., Bogdanova, T., \& Silchenkova, S. (2018). Philosophy of the profession in the structure of school teacher professional identity in Latvian and Russian samples. Society Integration Education Vol 2 169-179.

Karousiu, C., Hajisoteriou, C., Angelides, P. (2019).Teachers' Professional Identity in super-diverse school settings: Teachers as agents of intercultural education. Teachers and Teaching, Theory and Practice Vol 25, (2), 240-258

Kraft, M. A \& Falken, G. T. (2020). Why school climate matters for students and teachers. State Education Standard. Vol 20 pg 33-35.

Katsantonis, G.I. (2019). Investigating the impact of school climate and teachers' selfefficacy on job satisfaction: A cross cultural approach. University of Patras, Greece.

Lankveld, T.V., Schoonenboom, J., Volman, M., Croiset, G., \& Beishuizen, J. (2017). Developing a teacher identity in the university context: A systematic review of the literature. Higher Education Research \& Development, 36, (5), 325 - 342.

Lightfoot, S. \& Frost, D. (2015). The professional identity of early years educators in England: Implications for a transformative approach to continuing professional development, Professional Development in Education, 41(2), 401-418, doi:10.1080/19415257.2014.989256. 
Moloney, M. (2010). Professional identity in early childhood care and education: Perspectives of pre-school and infant teachers. Irish educational studies, 29(2), $167-$ 187.doi:10.1080/03323311003779068.

Moloney, M. (2015).Untangling the Knots, [K]not easy: Professional identity in early childhood and care and education sector. (Conference paper) presented in Early Education Alignment: Reflecting on context and curriculum pedagogy, at trinity College, Dublin.

Moloney, M., \& Pope, J. (2013). Where to now for early childhood care and education graduates? A study of the experiences of Irish BA ECCE degree graduates. International Journal of Primary, Elementary and Early Year's education. Education, 43(2), 142-152.

Mosomi, M. (2015). Job environment and satisfaction among preschool teachers in Kisii County, Kenya. (Master's thesis, Kenyatta University: Kenya).

Osher, D., Neiman, S. \& Williamson, S. (2020). School climate and measurement. State Education Standard, 20 (2), p23-27.

Raman, A., Ling, C., \& Khalid, R. (2015). Relationship between school climate and teachers commitment in an excellent school of Kubang Pasu District, Kedah, Malaysia. Mediterranean Journal of Social Sciences 6(3). Doi:10.5901/mjss.2015.V6n3S/P63.

Rennie Centre (2017). Understanding school climate and measurement: A Research Brief, Boston College.

Schacter, J., and Thum, Y. M. (2004). Paying for high-and low-quality teaching. Econ. Educ. Rev. 23, 411-430. doi: 10.1016/j.econedurev.2003.08.002

Thapa, A., Cohen, J., Guffey, S., \& Higgins-D'Alessandro, A. (2013). A review of school climate research. Review of Educational Research, 83, 357-385. 